\title{
Bilgisayar Destekli Öğretimin “Güneș Sistemi ve Ötesi, Uzay Bilmecesi” Ünitesindeki Öğrenci Başarısına ve Derse Karşı Öğrenci Tutumuna Etkisi
}

\section{The Impact of Computer Aided Education on the Student Success and the Student Attitude against the Lesson in the "Solar System and Beyond, Space Riddle" Unit}

\author{
Regaip ŞAHIN \\ Kafkas Üniversitesi, Fen Bilimleri Enstitüsü, Illkögretim A.B.D., Kars \\ e-posta: $\underline{\text { Rsahin66@hotmail.com }}$
}

Uğur AKBABA

Kafkas Üniversitesi, Eğitim Fakültesi, Matematik ve Fen Bilimleri Eğitimi Bölümü, Fizik Eğitimi A.B.D., Kars e-posta:ugurakbaba@hotmail.com

\begin{abstract}
Atıf: Şahin, R. \& Akbaba, U. (2018). Bilgisayar Destekli Öğretimin "Güneş Sistemi ve Ötesi, Uzay Bilmecesi” Ünitesindeki Öğrenci Başarısına ve Derse Karşı Öğrenci Tutumuna Etkisi. E-Kafkas Eğitim Araştırmaları Dergisi, 5(1), 10-24.
\end{abstract}

Gönderi Tarihi: 24-09-2017

Kabul Edilme Tarihi: 20-02-2018

DOI: $10.30900 /$ kafkasegt.339721

$\ddot{O}_{z e t}$

$\mathrm{Bu}$ araştırma, Milli Eğitim Bakanlığının belirlediği bilgisayar destekli öğretim tekniklerine uygun olarak hazırlanmıştır. Çalışmada, Fen ve Teknoloji dersindeki kazanımlara erişimde bilgisayar destekli öğretim metodunun etkisi incelenmiştir. Bu amaçla "Güneş Sistemi ve Ötesi, Uzay Bilmecesi” ünitesinin soyut olan kavramları ele alınmıştır. Görsel ve işitsel olarak somutlaştırması güç olan bu kavramların öğretilmesinde bilgisayar destekli öğretim yönteminin etkisi araştırılmıştır. Bir devlet okulunun 7. sınıfında eğitimlerine devam eden yirmişer kişilik erkek ve kız öğrenciden oluşmuş iki sınıf ele alınmıştır. Biri deney diğeri ise kontrol grubu olarak atanmıştır. Dersin hedeflerine uygun olduğunu düşündügümüz bilgisayar yazılım ve programları ile ünite, deney grubunda bilgisayar destekli öğretim yöntemi ile işlenmiştir. Ünitenin hedefleri, kontrol grubuna ise geleneksel yöntemle kazandırılmaya çalışılmıştır. Veri toplama araçları fen ve teknoloji dersi tutum ölçeği ve üniteye ait başarı testiden oluşmaktadır. Veri toplama araçları kontrol ve deney gruplarına ön-test ve son-test olarak uygulanmıştır. Elde edilen test sonuçları istatistik paket programı olan SPSS-22 ile analiz edilmişitir. Yapılan t-testi analiz sonuçlarına göre; bilgisayar destekli öğretimin geleneksel yönteme göre öğrencilerin ünite içerisindeki soyut kavramları öğrenmelerinde daha etkili olduğu ve akademik başarılarının bu yöntemle artırdığı görülmüştür. Bunun yanında, bilgisayar destekli öğretim yönteminin derse karşı ögrenci tumunu değiştirmediği tespit edilmiştir.

Anahtar Kelimeler: Bilgisayar Destekli Öğretim, Fen ve Teknoloji Öğretimi, Öğrenci Başarısı ve Tutumu

Abstract

This research was prepared in accordance with the computer-aided teaching techniques determined by the Ministry of National Education. In the study, the effect of the computer-assisted teaching method on access to the achievements of Science and Technology course was examined. For this purpose, the abstract concepts of the "Solar System and Beyond, Spacecraft" unit were discussed. The effects of the computer aided teaching method have been investigated in teaching these concepts which are difficult to visualize and audibly embody. Two classes of twenty male and female students who continue their education in the seventh grade of a public school were dealt with. One of them was assigned as an experiment and the other as a control group. With the computer software and programs that we thought were appropriate to the objectives of the course, the unit was processed by the computer assisted teaching method in the experimental group. The targets of the unit were tried to be obtained by the traditional method for the control group. Data collection instruments consist of attitude scale of science and technology course and success test of the unit. The data collection instruments were applied as pretest and posttest to control and experimental groups. The obtained test results were analyzed with a statistical package program SPSS22. According to the t-test analysis results; it has been seen that computer-assisted instruction was more effective in learning abstract concepts in the unit than traditional methods and the academic achievement has been increased by this method. Besides, it has been determined that students attitude against the lesson did not change with the computer assisted teaching method.

Key Words: Computer- Aided Education, Science and Technology Education, Student Success and Attitude

${ }^{1} \mathrm{Bu}$ çalışma, Kafkas Üniversitesi, Fen Bilimleri Enstitüsü'nde Regaip Şahin tarafından hazırlanan yüksek lisans tez çalışmasının bir bölümüdür. (2016) 


\section{GİRIŞ}

Tüm dünyada bilim ve teknoloji alanında yaşanan yarışta, toplumlar sürekli değişim gösteren teknolojiye uyum sağlamak zorundadır. Eğitimin kalitesini artırmak, günümüz dünyasının ihtiyaçlarını iyi analiz etmekten geçer. Analiz sonucunda ortaya çıkan ihtiyaçları karşılayacak etkili bilimsel çalışmalar yürütmek gerekir. Yürütülen bu çalışmalar sonucunda ortaya çıkan bilgi teknolojilerini ise eğitime yansıtarak eğitimin kalitesini artırabiliriz. Eğitim, bireylerin önceki öğrendiği bilgiler ile sonradan öğrendiği bilgileri karşılaştırmalarına, bilgiyi anlamlandırmalarına ve güncel yaşamlarında fayda sağlayabilmelerine yardımcı olmalıdır. Ancak fen ve teknoloji eğitiminde bu amaçtan uzaklaşıldığı ve sorunların aşılmasında belirli kalıpların kullanıldığı görülmektedir. Birçok eğitimci kavramları ve konuları öğrencilere direkt olarak aktarmaya çalışmaktadır. Bu ise eğitimin bilindik bir sorunu olarak her yerde karşımıza çıkmaktadır. Ezbere dayanan öğrenmelere sebep olan bu tutumlar, etkili öğrenmeye engel olmakta ve kalıcı öğrenmeler gerçekleşememektedir (Ar1c1, 2013:5).

Etkili bir fen öğretimi için teknolojiden faydalanmak oldukça önemlidir. Bu bağlamda fen öğretimi öne çıkmaktadır. Bilgisayarlar eğitim alanında kullanılabilecek teknolojik araçların başında gelmektedir (Ayas, 1993). Bireylerin zihinsel becerilerini olgunlaştırmalarında, fen öğretimi oldukça etkilidir. Bu zihinsel beceriler analitik düşünme, karşılaştırma, değerlendirme yeteneği gibi üst düzey düşünme gerektiren yeteneklerdir. Öğrencilerin yeteneklerini geliştirmelerine fen öğretiminde bilgisayar destekli öğretim yöntemlerinden faydalanmak etkili olmaktadır” (Çepni, 2008). Yüksek düşünme becerilerini geliştirecek, anlamlı öğrenmeyi sağlayacak ve özellikle soyut kavramları içeren konularda fen derslerinin öğrencilerin ilgisini çekecek şekilde organize edilip uygulanması gerekmektedir (Sönmez, vd. 2005).

$\mathrm{Bu}$ amaç için bilgisayar teknolojisinin büyük bir etkiye sahip olacağı düşünülmekle birlikte, yapılan araştırmalarında bu düşüncemizi desteklediği görülmektedir. Yapılan araştırmalarda; Sökücü (2014), İngilizce öğretmenlerin bilgisayar destekli dil eğitimine karşı tutumlarını araştırmıştır. Araştırmasının sonucunda; araştırmaya katılan öğretmenlerin çoğunluğunun bilgisayar destekli öğretime karşı olumlu tutuma sahip olduklarını ortaya koymuştur. Öz (2014), insanda dolaşım ve sindirim sistemi konularına uygun olarak hazırlanan bilgisayar destekli öğretim materyallerinin öğrenci başarısına, bilgi kalıcılık düzeyine ve bilgisayara karşı tutumuna etkisini incelemiştir. İnceleme sonucunda ise bilgisayar destekli öğretim yönteminin, öğrencilerin derse karşı tutumlarını, akademik başarılarını ve bilgilerinin kalıcılığını pozitif yönde etkilediğini görmüştür. Taş (2014), bilgisayarın eğitimde kullanılması ile ilgili olarak yapmış olduğu çalışmada, yönlendirme ve rehberlik görevleriyle birlikte bilgisayarların öğretmene yardımcı olduğunu ve öğretmenin yükünü hafiflettiğini ortaya koymuştur. Yapılan çalışmalar bilgisayarın zaman, mekân ve maliyet gibi unsurlarda büyük tasarruf sağlayarak, öğretmenin öğrencilerle birebir ilgilenme firsatı sunduğunu desteklemektedir. Bilgisayar destekli öğretim yöntemi çalışmaları sayesinde; öğrencinin hızı, öğrenme stili, kapasitesi ve yeteneği gibi bireye özgü öğrenme becerileri tespit edilmiştir. Bu çalışmalar neticesinde, bireylerin farklı özelliklerine göre oluşturulan eğitim ortamı uygulamalarının, eğitimin çağdaşlaşmasına katkı sağladığı sonucuna ulaşılmıştır.

Başkaya (2015), İstanbul'daki okullarda ders veren ilköğretim branş öğretmenlerinin bilgisayar destekli eğitim hakkında ki tutumlarının cinsiyet, yaş, öğretmenlik mesleğindeki hizmet yılı, branşı, bilgisayar ile ilgili herhangi bir hizmetçi eğitim ya da kurs alma vb. gibi özelliklere göre farklılık gösterip göstermediğine dair elde edilen verileri incelemiştir. İnceleme sonucunda branş öğretmenlerinin bilgisayar destekli eğitime ilişkin olumlu tutumlara sahip olduğu sonucuna ulaşmıştır. Araştırmacı, bu olumlu tutumun öğretmenlerin branşına, yaşına, cinsiyetine, mesleki kıdemine ve öğrenim düzeylerine göre değişip değişmediğini ele almıştır ve belirtilen değişkenlerin öğretmenlerin tutumlarında farklılığa yol açmadı̆̆ını görmüştür. Yine araştırma sonuçlarına göre öğretmenlerin, üniversite eğitimi süresince bilgisayar dersi alıp almamasına, bilgisayarla ilgili herhangi bir kurs alıp almamasına ve evlerinde bilgisayar olup olmamasına göre bilgisayara karşı tutumlarında anlamlı bir farklılık bulunamamıștır.

Yechshzhanova (2014), bilgisayar destekli öğrenme ve mobil öğrenme yöntemi için geometri dersinin içeriğini 3DS MAX ve UNITY3D programlarında geliştirerek Unity3D programına aktarmak suretiyle öğrencilerin kullanımına sunmuştur. Yaptığı çalışma neticesinde öğrencilerin akademik başarısının arttığını görmüştür.

Zonturlu (2014), Öğrencilerin özerklik gelişimi algıları hakkında iç görü kazanma ve öğrencilerin bilgisayar destekli dil öğrenimi ortamında ingilizce öğrenme algılarını araştırmıştır. Araştırmasının sonucunda ise bilgisayar destekli dil öğrenimi ortamında ingilizce öğrenme algılarının arttığı ve öğrencilerin çoğunluğunun yüksek bir isteklenmeye sahip olduğu sunucuna ulaşmıştır.

Düzkaya (2014), lise öğrencilerinin kimyasal reaksiyonlar konusundaki zihinsel döndürme becerilerine bilgisayar destekli öğretim ve somut nesnelerin etkisi konusunu araştırmıştır. Araştırma sonucunda bilgisayar destekli öğretimin öğrencilerin uzamsal düşünme becerileriyle kimyasal reaksiyonlar konusundaki zihinsel döndürme becerilerini anlamlı şekilde geliştirdiğini görülmüştür.

Karaçöp, Doymuş ve Doğan (2009); yaptıkları çalışmada Jigsaw tekniği ile birlikte bilgisayar 
animasyonlarını kullanarak fen bilgisi öğretmenliği 1. sınıf öğrencilerinin, elektrokimya ünitesindeki akademik başarıları incelenmiştir. Kimya Akademik Başarı Testi ve Bilimsel Düşünme Beceri Testi sonuçlarına göre bilgisayar animasyonları ile öğretim yapılan deney grubunda başarı düzeyinin geleneksel öğretim yapılan gruba göre daha yüksek olduğunu tespit etmişlerdir.

Fen ve teknoloji dersi; öğrencilerin kendi kendine çalışarak, öğretmenin rehberlik ettiği, yaparak yaşayarak, hayatta gerekli bilgi ve davranışların öğrenildiği öğrenci merkezli bir derstir. Fen ve teknoloji dersi belirtilen bu yaklaşımlar üzerine şekillenmektedir. Bilgisayar teknolojisinin fen ve teknoloji eğitiminde etkili bir şekilde kullanılmasıyla öğrenciler bilgileri daha hızlı ve kolay bir şekilde elde etmektedir. Ayrıca öğrenciler bilgisayar teknolojisini kullanarak da öğrendikleri bilgileri yaşadıkları hayatla ilişkilendirme imkânı bulabilirler.

Bilgisayar destekli öğretimin temel unsurlarından biri olan bilgisayar teknolojisi teknolojisi eğitimin vazgeçilmez bir parçasıdır. Öğretimin gerçekleştiği süreçleri ve öğrencilerin derse olan ilgi, alaka ve tutumlarını güçlendirir. $\mathrm{Bu}$ teknolojiden öğrenci kendi öğrenme zorluklarına göre faydalanabilmektedir. Öğrenmenin gerçekleştirildiği süreçte bir ortam aracı olarak kullanılmaktadır. Bilgisayar destekli öğretim kendi kendine öğrenme ilkelerinin bilgisayar teknolojisi ile birleşmesinden oluşmuş bir öğretim yöntemi olarak ifade edilmektedir (Uşun, 2000). Bilgisayar destekli öğretimi; Şahin ve Yıldırım, (1999) öğretim ile ilgili içerik veya faaliyetlerin bilgisayar yoluyla aktarılması; Yalın, (2002) öğrencilere bir konu veyahut kavramı öğretmek amacıyla bilgisayar yazılımları ile geliştirilen ders içerikleri sayesinde, önceden kazandırılan davranışları pekiştirmek için kullanılması olarak ifade etmektedirler. Bilgisayar destekli öğretim, bilgisayarların dersin içeriğine uygun olarak hazırlanan yazılımlar sayesinde öğrencilerle etkileşimde bulunduğu, bilgi ile öğrenci arasında bir aracı olarak kullanılan, öğretmenin ise yol gösteren olduğu etkinlikler bütünü olarak tanımlanabilir. Başka bir tarifinde ise eğitimsel etkinlik ve muhtevaların bilgisayar teknolojisi aracılı̆̆ıla öğrencilere nakledilmesidir (Hannefin and Peck, 1988). Bazı öğrencilerin öğretim sürecinde öğrenemedikleri konuların telafisinde bilgisayarın yardıma yetişmesi, bilgisayar destekli öğretimin olmazsa olmaz ve yadsınamaz bir ilkesini göstermektedir. Kimi zaman derste işlenen konularla istendik seviyeye gelemeyen öğrenciler, bu durumdan bilgisayar destekli öğretim yöntemiyle kurtulacaklardır. Öğrenciler kavrayamadıkları konuların ve sınavlardan düşük puan aldıkları derslerin telafisini yapabiliceklerdir. Bu telafiyide öğrenciler ders dışındaki zamanlarda bilgisayar laboratuarında çalışarak yapabileceklerdir. Bu sebeple kimi ülkelerde belirlenen ders içeriklerine yönelik bilgisayar yazılımları geliştirilmiştir. Eğitim videoları oluşturularak, eğitim öğretim sürecinde öğretmen ve öğrencilerin kullanımına sunmak suretiyle hazır hale getirilmiştir. Böylelikle bilgisayarlar eğitim öğretim sürecinde her zaman için öğretmen ve öğrenciye yardımcı bir unsur olarak görev almaktadır.

Bilgisayar teknolojisiyle oluşturulan ortamda karşılıklı iletişim olanağı bulan bireyler bu ortamları gerçekmiş gibi hissederler. Bilgisayar teknolojisi; eğlence dünyasından tıp dünyasına kadar birçok uygulama alanı bulmuştur. Sanal uygulamalarıyla bilgisayarlar eğitim alanında da giderek yaygın hale gelmiştir. Uşun (2004), Bilgisayar Destekli Öğretim'in öğretmene, öğrenciye ve eğitime katkıları Barker and Yeates (1985), den aşağıdaki gibi aktarmıştır; $\mathrm{Bu}$ yöntem derslerde geleneksel öğretim yöntemlerini aktif hale getirir. Öğrenmeye ayrılan süreyi kısaltır. Dar, kısıtlı materyaller yerine zenginleştirilmiş materyaller sunar. Pahalı ve etkili olmayan öğretimden kurtulmayı sağlar. İhtiyaçları karşılamak için tekrar olanağı sunar. Bireye özgü öğretimi gerçekleştirmek yolu ile öğretimin kalitesini artırır. Bilginin daha çok sayıda öğrenciye iletilmesi olanağı sağlaması, kısa zamanda daha etkin öğrenme sağlaması ve daha az rutin işlem içermesi bu yöntemin öğretmene olan katkılarıdır. Değerlendirme ve not verme işlemlerinin minimuma indirgenmesi, öğrenciler ve öğreticiler arasında iletişimi artırması, öğrencilere süreçte daha fazla sorumluluk yüklemesi, bilgiye ucuz ve kolay erişim sunması da yöntemin öğretmene sunduğu diğer avantajlardır.

$\mathrm{Bu}$ yöntem, öğrencilere kendi hazır bulunuşluk düzeylerine göre çalışabilme olanağı verir. Öğrenme sürecinde öğrenciye mesuliyet yükler. Tekrar olanağı ile birlikte öğrencinin bilgi ile birebir etkilşimini sağlar. Her türlü ders içeriğini, similasyon ortamlarını donanım güçü ile öğrenciye sunar. Genel olarak Bilgisayar Destekli Öğretimin eğitime katkılarını genel olarak şöyle aktarılmıştır; Öğretimin etkinliğini artırıp eğitimin kalitesini yükselttir. Zaman tasarrufu sunarak dersleri ilginç kılar. Hazır bulunuşluk düzeyleri farklı öğrencilere ulaşma imkânı sunar. Farklı içerikte erişim imkânları sunarak, geniş öğrenme ortamları oluşturur. Teknolojiye ayak uydurma becerisi geliştirir.

$\mathrm{Bu}$ araştırmanın temel amacı bilgisayar destekli öğretimin ortaokul öğrencilerinin Güneş Sistemi ve Ötesi, Uzay Bilmecesi ünitesindeki akademik başarılarına ve bilgilerin kalıcılığına etkisini incelemektir. Ayrıca bilgisayar destekli öğretim yöntemi ile öğrenim gören öğrencilerin öğretim sürecine ilişkin görüşlerinin belirlenmesidir. Araştırmada aşağıdaki alt problemlere cevap aranmıştır.

1. Bilgisayar destekli öğretim ve geleneksel öğretim yöntemleri ile öğrenim gören öğrencilerin ön bilgi düzeyleri arasinda anlamlı farklılık var midır?

2. Bilgisayar destekli öğretim ve geleneksel öğretim yöntemleri ile öğrenim gören öğrencilerin sontest başarı puanları arasında anlamlı farklılık var mıdır? 
3. Bilgisayar destekli öğretim ve geleneksel öğretim yöntemleri ile öğrenim gören öğrencilerin fen ve teknoloji dersine karşı tutum düzeyleri arasında sontest puanları açısından anlamlı farklılık var mıdır?

\section{YÖNTEM}

Araştırma, bilgisayar destekli öğretim yönteminin fen ve teknoloji dersinin amaçlarına erişim düzeyine etkisinin araştırıldığı kontrol gruplu ön test-son test (Karasar,2005: 174) biçimine uygun yarı deneysel bir çalışmadır.

Tablo 1: Ön Test- Son Test Kontrol Gruplu Araşstrrma Deseni

\begin{tabular}{cccc}
\hline Guruplar & Ölçme & Deneysel çalı̧̧ma & Ölçme \\
\hline Kontrol & $\begin{array}{c}\text { Ön-Test (6. yllsonu başarı } \\
\text { puanı) }\end{array}$ & Geleneksel Yöntem & Son-Test \\
\hline Deney & $\begin{array}{c}\text { Ön-Test (6. yllsonu başarı } \\
\text { puanı) }\end{array}$ & $\begin{array}{c}\text { Bilgisayar Destekliöğretim } \\
\text { Yöntemi }\end{array}$ & Son-Test \\
\hline
\end{tabular}

Modelin işleyişi yukarıda gösterilmiştir. Araştırma, Bayburt il merkezinde bilgisayar donanımlı Bayburt ili; Şehit Recep Eşiyok Ortaokulu 7. sınıf düzeyinde belirlenen deney grubu ve kontrol grubu sınıflarında Güneş Sistemi ve Ötesi, Uzay Bilmecesi ünitesi üzerinde gerçekleştirilmiştir. Güneş Sistemi ve Ötesi, Uzay Bilmecesi ünitesinin hedeflerinin gerçekleşme düzeyi; bilgisayar destekli öğretim yöntemiyle ders alan öğrenciler (deney grubu) ile geleneksel yöntemlerle ders alan öğrencilere (kontrol grubu) uygulanan erişi testinde elde ettikleri başarı düzeyine göre ölçülmüsşür. Araştırmanın gerçekleştirildiği okulda öğrencilerin temel bilgisayar kullanma becerilerine yönelik eğitim ve geliştirme çalışmaları ile bilgisayar destekli öğretimin yapılabilmesi için gerekli teknolojik altyapıda standartlara uygunluk sağlanmıştır. Ayrıca öğrencilerin bilgisayar becerisi yeterlilikleri de aynı olduğu yapılan uygulama neticesinde gözlemleme yolu ile tespit edilmiştir. Bilgisayar destekli öğretim yöntemiyle işlenen derste kullanılan Solar System Scope adlı programdan alınmış ekran görüntülerinden örnekler Ek 1'de gösterilmiştir.

\section{Araşttrmanin evren ve örneklemi}

Evren araştırma sonuçlarının genellenmek istendiği elemanlar bütünü, örneklem ise belli bir evrenden belli kurallara göre seçilmiş ve seçildiği evreni temsil yeterliği kabul edilen küçük kümedir (Karasar, 2005). Çalışmanın evrenini Bayburt il merkezinde yer alan Şehit Recep Eşiyok Ortaokulu öğrencileri oluşturmaktadır. Örneklemi ise, aynı okulda araştırmanın amacına uygun olan yedinci sınıf öğrencileri oluşturmaktadır. Araştırma gurubunu ise aynı ortaokuldaki 7A sınıfinda bulunan 20 öğrenci (Deney grubu; 9 kız, 11 erkek) ve 7B sınıfinda bulunan 20 öğrenci (Kontrol grubu; 12 kız, 8 erkek) olmak üzere toplam 40 öğrenci oluşturmaktadır.

\section{Veri toplama araçlart}

Verilerin toplanması sürecinde deney ve kontrol grubundaki öğrencilere 4 haftalık ders işleme sürecinden sonra Fen ve Teknoloji Dersi Tutum Ölçeği ve aynı ders için geliştirilen Başarı Testi uygulanarak çalışmanın verileri elde edilmiştir. Ön-test olarak çalışmaya katılan öğrencilerin 6. sınıf fen ve teknoloji dersi yılsonu sınav puanları kullanılmışıır. Çalışmada Fen ve Teknoloji Başarı Testi olarak, Arıcı, (2013)'nın çalışmasında aşağıda belirtilen yolları izleyerek geliştirdiği ve güvenirlik katsayısı 0.76 olan 20 soruluk astronomi başarı testi kullanılmıştır. Veri toplama aracı olarak Arıcı, (2013) tarafindan çoktan seçmeli 4 seçenekli 50 test maddesi uygulanmıştır. Test maddelerini hazırlarken söz konusu ünitenin kazanımları göz önüne almıştır. Her kazanımdan 1 ile 3 adet arası test maddesi hazırlanmış ve bu test bilgi, kavrama ve uygulama düzeyindeki soruları içermiştir. Hazırlanan test iki fen ve teknoloji öğretmenine, fen eğitimi alanında uzman bir öğretim üyesine ve 50 adet 8 . sınıf öğrencisine uygulanmıştır. Anlaşılmayan yerler düzeltilmiş, değiştirilmesi gereken sorular değiştirilmiş̧tir. Testin son hali iki ilköğretim okulundan seçilen 8. sinıf öğrencilerine $(\mathrm{N}=120)$ uygulanmıştır. Uygulama sonucunda ölçekler incelenerek düzgün doldurulmamış testler atılmış ve 108 öğrencinin testi değerlendirmeye alınmıştır. Uygulama sonucu elde edilen veriler SPSS istatistik programında Cronbach Alfa güvenirlik analizi kullanılarak analiz edilmiş̧ir. Analiz sonucuna göre araştırmacı madde ayırt edicilik indeksi 0.30 'un altında olan 30 madde testten çıkarmıştır. Geriye kalan yirmi (20) maddelik başarı testi ortalamasının 9.46, standart sapmasının 3.16 olduğu görülmüştür. Yapmış olduğu SPSS istatistik sonucunda ise 20 soruluk başarı testinin Cronbach's Alpha güvenilirlik katsayısını 0.76 olarak bulmuştur.

Alfa katsayısının bulunabileceği aralıklar ve buna bağlı olarak da ölçeğin güvenirlik durumları dikkate alındığında; $0,00 \leq \alpha<0,40$ ise ölçek güvenilir değildir, $0,40 \leq \alpha<0,60$ ise ölçek düşük güvenilirliktedir, 0,60 $\leq \alpha<0,80$ ise ölçek oldukça güvenilir bir ölçektir (Öz, 2014). Sonuç olarak yukarıdaki yöntemleri izleyerek Arıc1, (2013)'ün oluşturduğu güvenirlik kat sayısı 0.76 olarak ölçülen ve oldukça güvenilir olan yirmi soruluk 
başarı testi kullanılmıştır.

Araştırmada; Balım, vd. (2009) tarafindan geliştirilen Cronbach Alpha ölçüm güvenirlik katsayısı 0,94 olarak bulunan ve üç alt faktörde toplanan, 44 tutum maddesinden oluşan Fen ve Teknolojiye Yönelik Tutum Ölçeği kullanıılmıştır. Ölçekten alınabilecek en düşük puan 44, en yüksek puan ise 176'dır. Ölçek 21 madde içeren Cronbach Alpha ölçüm güvenirlik katsayısı 0,91 olan hoşlanmama (olumsuz duygular), 17 madde içeren Cronbach Alpha ölçüm güvenirlik katsayısı 0,91 olan olumlu duygular ve 6 madde içeren Cronbach Alpha ölçüm güvenirlik katsayısı 0,74 olan fen ve teknolojiye yönelik ilgi alt boyutlarından oluşmaktadır. Ölçeğin geliştirilme aşamalarında araştırmacılar aşağıdaki yolu izlemişlerdir.

$\checkmark \quad$ Madde havuzunun oluşturulabilmesi amacıyla 55 öğrencinin fen ve teknolojiye ilişkin görüşleri alınmıştır. Öğrenci görüşleri ve daha önce hazırlanan tutum ölçekleri incelenerek 57 madde belirlenmiştir.

$\checkmark \quad$ Kapsam geçerliğini sağlamak amacıyla uzman görüşleri alınmıştır.

$\checkmark \quad 20$ kişilik bir öğrenci grubuna uygulanmış ve uygulamada zorlandıkları maddeler belirlenerek deneme uygulaması yapılmıştır.

$\checkmark \quad$ Görüş ve öneriler doğrultusunda 62 maddelik ölçeğin deneme formu oluşturulmuş ve 15 ilköğretim okulunda uygulanmıştır.

$\checkmark \quad$ Uygulamalar sonucu toplanan verilerin faktör analizi yapılmıştır.

$\checkmark \quad$ İstatistiksel çalışmalardan sonra 44 madde ve üç boyuttan oluşan Fen ve Teknolojiye Yönelik Tutum Ölçeği oluşturulmuştur.

Araştırmada kullanılan Fen ve Teknoloji dersi başarı testinde yer alan sorulardan örnekler ve tutum ölçeği sırasıyla Ek 2 ve Ek 3 te sunulmuştur.

\section{Verilerin analizi}

Çalı̧̧mada elde edilen verilerin niteliğine uygun istatistiksel analizleri yapılmıştır. İstatistiksel analizler için SPSS 22.00 paket programı kullanılmıştır. İstatistiksel analiz yapılmadan önce, verilerin normal dağılım sergileyip sergilemedikleri incelenmiş̦tir. Bunun için SPSS 22.00 paket programında normallik testi uygulanmış ve verilerin normal dağılım sergilediği görülmüştür. $\mathrm{Bu}$ sebeple araştırmada $\mathrm{t}$ - testi kullanılmıştır. $\mathrm{Bu}$ testler kullanılmadan önce bazı varsayımları sağlaması gerekmektedir. Bu sebeple t- testi varsayımları incelenmiş ve gerekli varsayımların sağlandığı görülmüştür.

\section{BULGULAR}

Araştırmanın birinci ve ikinci alt problemlerinin çözümü için deney ve kontrol guruplarının ön test ve son test sonuçları t- testi ile karşılaştırma yapılmıştır.

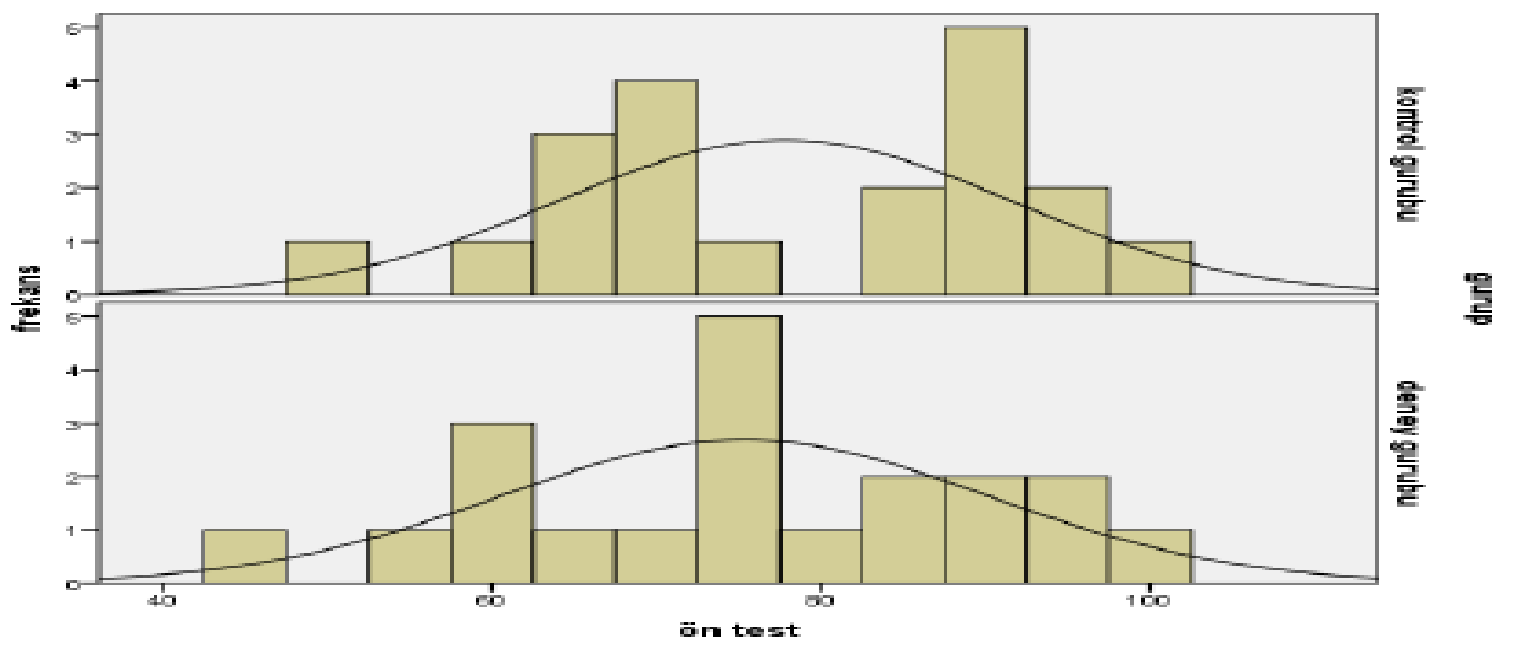

Şekil 1. Ön- test frekans dă̆gllımı grafĭgi

Köroğlu ve Yeşildere (2004), yapmiş oldukları araştırmada 7D ve 7E sınıflarından oluşan deney ve kontrolguruplarının başlangıç seviyelerini belirlemek amacıyla ön test olarak bu sınıfların 6. sınıf yılsonu başarı not ortalama puanlarını değerlendirmeye almıştır. Literatürde yapılan bu çalışma dikkate alınarak araştırmamızda ön test sonuçları olarak öğrencilerin yılsonu 6. sınıf fen ve teknoloji dersi sınav puanları kullanılmıştır. Bayburt Şehit Recep Eşiyok Ortaokulundan alınan öğrencilerin 6. Sınıf fen ve teknoloji dersi yılsonu sınav puanları analiz edilmiştir. Yapılan istatistik analizlerde öğrencilerin ön test sonuçlarında anlamlı fark çıkmamıştır. Deney ve kontrol gurubu ön test 6 . sınıf fen ve teknoloji dersi yılsonu sınav puanları t-testi ile analiz sonuçları tablo 1 . de verilmiştir. 
Tablo 1.

Deney ve Kontrol Guruplarının 6. Sinıf Fen ve Teknoloji Dersi Yılsonu Sinav Puanlarının t- Testi Analizi

Sonuçlart

\begin{tabular}{|c|c|c|c|c|c|c|}
\hline & Gruplar & $\bar{X}$ & SS & sd & $\mathbf{t}$ & $\mathbf{p}$ \\
\hline \multirow{3}{*}{ Ön test } & Kontrol grubu & 77,80 & 13,763 & & & \\
\hline & & & & 38 &, 541 &, 592 \\
\hline & Deney grubu & 75,35 & 14,876 & & & \\
\hline
\end{tabular}

Tablo 1'e göre deney ve kontrol grubu öğrencilerinin akademik başarı puanları arasında istatistiksel olarak anlamlı bir farkın olmadığı görülmektedir $(\mathrm{t}=0,541 ; \mathrm{p}=0,592 ; \mathrm{p}>0,05)$. Deney grubundaki öğrencilerin ön test akademik başarı puan ortalaması $(X=77,80)$ kontrol grubundaki öğrencilerin akademik başarı ortalaması ise $(X=5,35)$ olarak bulunmuştur. $\mathrm{Bu}$ durum grupların uygulama öncesinde akademik başarı aritmetik ortalamalarının birbirine yakın düzeyde olduğunu göstermektedir.

Deney ve kontrol grubunda yer alan öğrencilerin deneysel çalışma sonrasında uygulanan son test akademik başarı puanlarına ilişkin bağımsız t-testi analiz sonuçları Tablo 2'de verilmiştir.

Tablo 2.

Deney ve Kontrol Guruplarının Son Test Akademik Başarı Puanlarının Spss-22 Paket Programı ile t- Testi Analizi Sonuçları

\begin{tabular}{ccccccc} 
& Gruplar & $\bar{X}$ & ss & df & t & p \\
\hline \multirow{2}{*}{ Son test } & Kontrol grubu & 48,75 & 18,128 & & & \\
& Deney grubu & 77,00 & 12,503 & & $-5,737$ & .001 \\
\hline
\end{tabular}

Tablo 2'deki bulgular incelendiğinde deney ve kontrol grubunda bulunan öğrencilerin, son test akademik başarı puanları için uygulanan t-testi sonuçlarında istatistiksel olarak anlamlı bir farklılık olduğu görülmektedir $(\mathrm{t}=5,737 ; \mathrm{p}=0,001 ; \mathrm{p}<0,05)$. Deney grubundaki öğrencilerin son test akademik başarı puan ortalamalarının $(X=77,80)$ kontrol grubundaki öğrencilerin son test akademik başarı puan ortalamalarından $(X=48,75)$ yüksek olduğu bulunmuştur. Analizler sonucunda 6. Sinıf fen ve teknoloji dersi yılsonu akademik başarı puan ortalamaları arasında anlamlı farklılık bulunmayan grupların son testler sonrasında akademik başarı puan ortalamaları incelenen deney grubundaki öğrencilerin akademik başarılarının kontrol grubundaki öğrencilerden daha yüksek olduğu görülmektedir. 


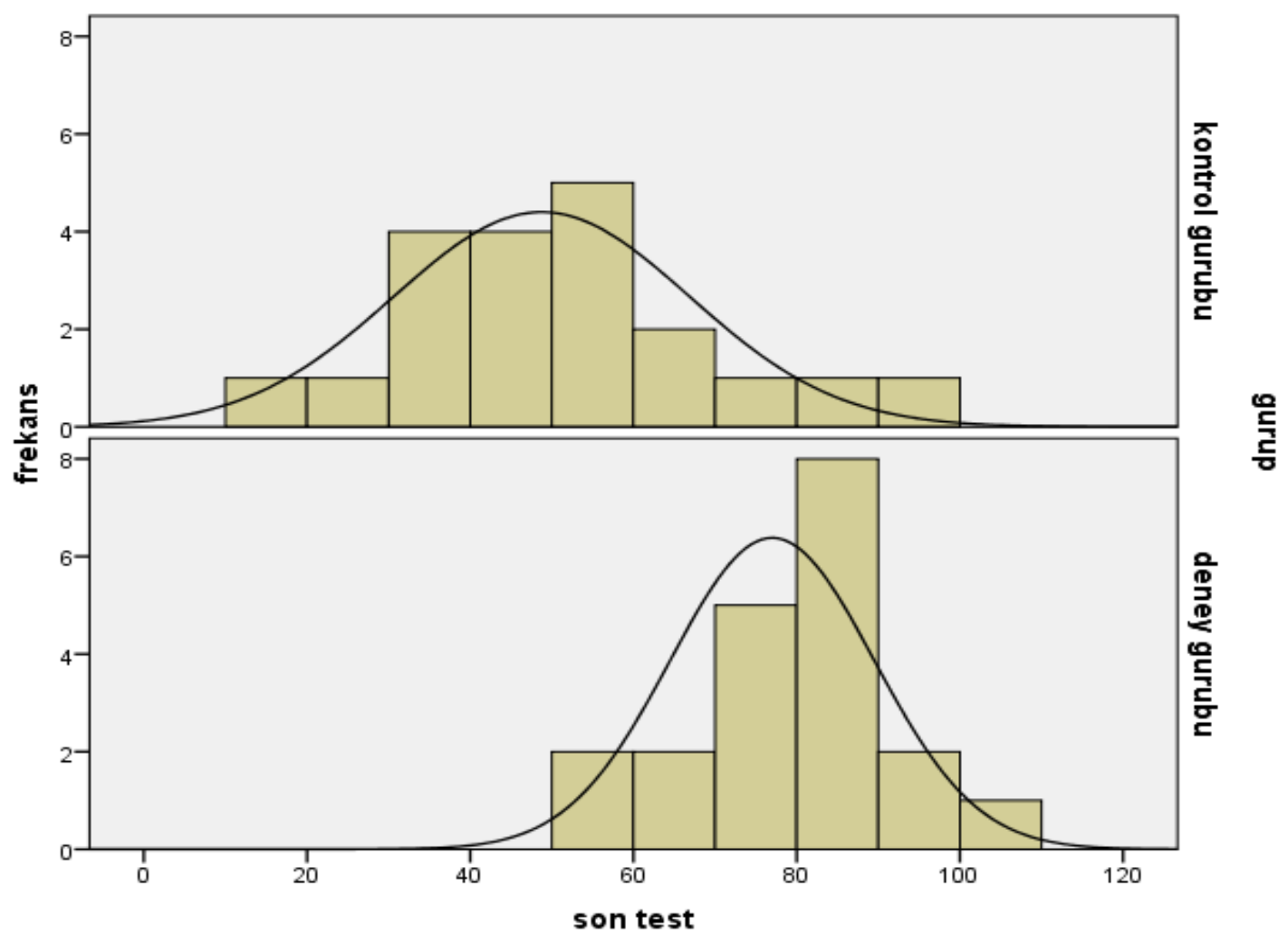

Şekil 2. Son- test frekans dă̆glımı grafĭgi

Araştırmanın üçüncü alt problemi olan deney ve kontrol grubundaki öğrencilerin fen ve teknoloji dersine karşı tutum düzeyleri arasında bir farklılık olup olmadığını ortaya çıkarmak için çözümü için deney ve kontrol guruplarının tutum ölçeği son test sonuçları t- testi ile karşılaştırılmıştır. Bağımsız gruplar t-testi uygulanmış ve elde edilen sonuçlar Tablo 3 'te sunulmuştur.

Tablo 3.

Deney ve Kontrol Guruplarının Son Test Akademik Tutum Puanlarının t- Testi Analizi Sonuçları

\begin{tabular}{|c|c|c|c|c|c|c|}
\hline & Gruplar & $\bar{X}$ & $\mathbf{s}$ & $\mathrm{df}$ & $\mathbf{t}$ & $\mathbf{p}$ \\
\hline \multirow{2}{*}{$\begin{array}{l}\text { Tutum } \\
\text { puanları }\end{array}$} & Kontrol grubu & 148,35 & 19,599 & \multirow{2}{*}{38} & \multirow{2}{*}{$-1,461$} & \multirow{2}{*}{.152} \\
\hline & Deney grubu & 156,60 & 15,919 & & & \\
\hline
\end{tabular}

Tablo 3'te ki bulgular incelendiğinde deney ve kontrol grubunda bulunan öğrencilerin, son test akademik tutum puanları için uygulanan t-testi sonuçlarında istatistiksel olarak anlamlı bir farklılık olmadı $\breve{g}_{1}$ görülmektedir $[\mathrm{t}(38)=-1,461 ; \mathrm{p}=0,152 ; \mathrm{p}>0,05]$. 


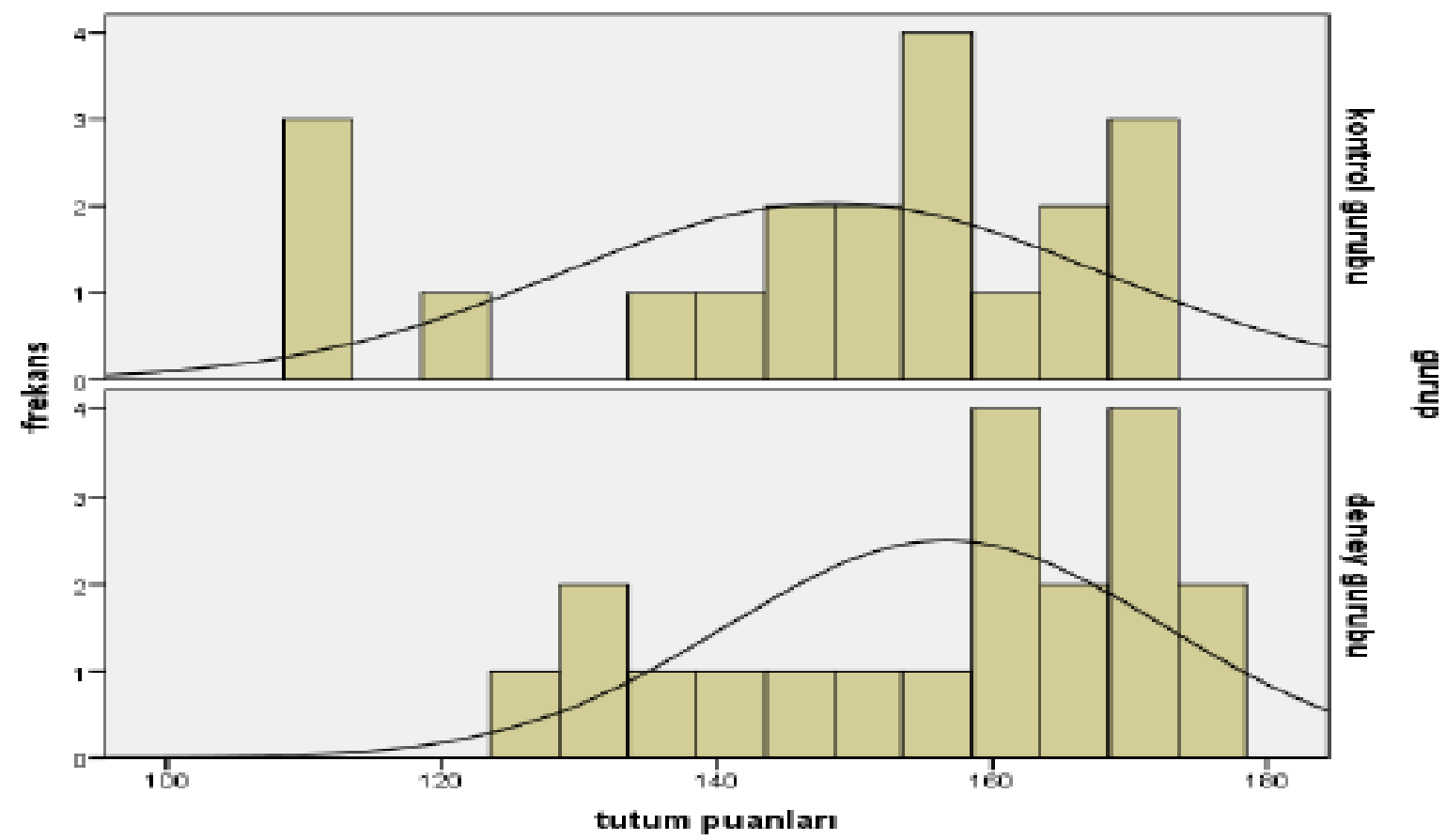

Şekil 3. Tutum puanlarl frekans dağllım grafiği

TARTIŞMA VE SONUÇ

Bu çalı̧̧mada, "Güneş Sistemi ve Ötesi: Uzay Bilmecesi” konusunun öğretiminde bilgisayar destekli öğretim yöntemi kullanılmasının, öğrencilerin başarısına ve derse karşı tutumlarına olan etki sonuçları verilerek tartı̧̧ılmışıır.

Araştırmanın sonuçlarına göre, deney ve kontrol gurubu arasında akademik başarıya yönelik olarak ön test ve son test sonuçlarının uygulama öncesinde 6. sınıf yılsonu fen ortalamalarının birbirine yakın olduğu ve aralarında herhangi bir fark olmadığı görülmektedir. Son test akademik başarı sonuçlarını acısından ise deney gurubu ortalaması kontrol gurubu ortalamasında yüksek çıktığı görülmüştür. Ayrıca bilgisayar destekli öğretim öğrencilerin fen dersine olan tutumlarında herhangi bir farklılık oluşturmadığı tespit edilmiştir. Bu sonuçları maddeler halinde ifade edecek olursak;

1. Bilgisayar destekli öğretim yönteminin uygulandığı deney grubundaki öğrencilerle, geleneksel öğretim yönteminin uygulandığı kontrol grubundaki öğrencilerin son test akademik başarı puanları arasında deney gurubu lehine anlamlı bir fark olduğu gözlemlenmiştir.

2. Bilgisayar destekli öğretim yönteminin uygulandığı deney grubundaki öğrencilerle, geleneksel öğretim yönteminin uygulandığ 1 kontrol grubundaki öğrencilerin son test fen ve teknolojiye yönelik tutum puanları arasında anlamlı bir farklılık olmadığı gözlemlenmiştir.

Bu bulguları destekleyen çalışmlarda literatürde mevcuttur. Öz (2014), biyoloji öğretiminde hazırlanan bilgisayar destekli öğretim materyallerinin başarı, kalıcılık ve bilgisayara yönelik tutuma etkisi (dolaşım ve sindirim sistemi örneği) çalışmıştır. Çalışmasında deney ve kontrol gurubu arasında akademik başarıya yönelik ön test ve son test sonuçlarından son test puan ortalamasının $(X=22,23)$ ön test puan ortalamasından $(X=8.60)$ anlamlı düzeyde yüksek olduğu görülmektedir $(\mathrm{p}=0,000)$. Bilgisayar destekli öğrenme yaklaşımına göre düzenlenen materyal uygulamalarının deney grubu öğrenenlerinin başarı düzeylerini artırdığı sonucuna ulaşmıştır. Yine aynı şekilde Hassan Zadeh Baran'ın (2014), araştırmasına bakıldığında, animasyonlu öğretim ile ders işleyen üniversite 2. sınıf fen bilgisi öğretmenliği okuyan öğrencilerin ve ortaöğretim 11. sınıf ögrencilerinin modern fizik (kuantum) son test ortalamalarına bakıldığında deney gurubu lehine anlamlı fark bulduğu görülmektedir. Akçay, Aydoğdu, Yıldırım ve Şensoy (2005); yaptıkları çalışmada bilgisayar destekli öğretim yöntemi ile anlatım yöntemin karşılaştırmışlardır. Yapılan analizler sonucunda bilgisayar destekli yöntemin 6. sınıf çiçekli bitkiler konusunda öğrencilerin akademik başarılarını artırdığı görülmüştür. Benzer şekilde ilköğretim 8. sınıf öğrencilerine maddenin yapısı ve özellikleri ünitesi özelinde bilgisayar destekli öğretim yöntemi uygulanmıştır. Yöntemin fen ve teknoloji dersine yönelik tutum ve dersdeki akademik başarı üzerine etkisi araştırılmıştır. Geleneksel öğretim yöntimi ile karşılaştırma yapılmıştır. Araştırma sonucunda 
bilgisayar destekli yöntemin akademik başarıyı artırtığı fakat derse karşı tutumda bir değişiklik meydana getirmediği tespit edilmiştir (Güven, Sülün, 2012). Çamlı (2009) ve Kahraman (2007)'nin çalışmalarında da uygulanan öğretim yöntemlerinin öğrencilerin fen dersine yönelik tutumları değiştimediği tespit edilmiştir. Fen dersi dışındaki başka derslerdede aynı şekilde karşılaştırmlar yapılmışıı. 6. sınıf matematik dersinde açılar ve üçgenler ünitesinde iki method karş̧laştırılmıştır. Yarı deneysel araştırma yöntemi uygulanmıştır. Araştırma sonucunda bilgisayar destekli öğretim yönteminin geleneksel yönteme göre öğrencilerin akademik başarılarını ve matematik dersine karş1 tutumlarını olumlu yönde etkilediği görülmektedir (Sulak, 2002). Matematik dersine karşı oluşan tutum açısından bizim çalışmamızdaki ve diğer çalışmalardaki sonuçlarla tezat bir sonuç çıkmıştır. Bizim çalışmamızda öğrencilerin fen ve teknoloji dersine yönelik tutumlarına bakıldığında öğrencilerin deney ve kontrol gurubunda ki öğrenciler arasında tutumlarında her hangi bir fark bulunmamıştır. Burada deney ve kontrol gurubu arasında ortalamaların birbirinden farklı çıkmamasının sebebi; öğrencilerin fen ve teknoloji dersine karşı ilgi ve meraklarının olması, öğrencilerin fen dersini sevmeleri, her iki grupta da tutum ortalamalarını yükseltmiştir ve aralarında anlamlı bir fark çıkmamıştır. Tumuma karşı bir değişikliğin olmamasının nedeni araştırmanın kısa bir zaman içinde gerçekleşmesi, öğrencilerin ilk kez böyle bir uygulama ile karşılaşmasından dolayı da olabilir (Altınışık ve Orhan 2002). Fakat Bilgisayar destekli eğitim ile ilgili olarak öğretmenlerin öğrenciler üzerinde ki etkililiğini artırmak, öğrencilerin gözünde bilgisayarın öğrenmede bir aracı olarak kullanıldığını anlamalarını sağlamaları gerekmektedir. Aksi halde öğrencilerde öğretmene karşı olumsuz durum oluşturabilecek davranışlar ortaya çıkabilir. Bunların yaşanmaması için öğretmenin derste etkin olması öğrencileri bilgisayar kullanırken yönlendirmesi için öğretmenlere hizmet içi eğitim verilmelidir (Öz, 2014).

Milli Eğitim Bakanlığımızın misyonunda şu ifadelere yer verilmektedir; Düşünme, anlama, araştırma ve sorun çözme yetkinliği gelişmiş, bilgi toplumunun gerektirdiği bilgi ve becerilerle donanmış, millî kültür ile insanlığın ve demokrasinin evrensel değerlerini içselleştirmiş, iletişime ve paylaşıma açık, sanat duyarlılığı ve becerisi gelişmiş, öz güveni, öz saygısı, hak, adalet ve sorumluluk bilinci yüksek, gayretli, girişimci, yaratıcı, yenilikçi, barışç, sağlıklı ve mutlu bireylerin yetişmesine ortam ve imkân sağlamaktır (http://www.meb.gov.tr/vizyon-misyon/duyuru/8851, 2015). Bu benimsenen misyonun yerine getirilmesinde bilgisayar destekli öğretim yönteminin etkili bir yöntem olacağı görülmüştür.

Sonuç olarak aşağıdaki öneriler yapılabilir;

Bilgisayar destekli eğitimin sadece fen ve teknoloji dersinde değil diğer tüm derslerde kullanılması öğrenci ve ögretmenlere çok faydalı olacaktır.

Solar Sytem Scope programı ile yapılan etkinliklerde öğrencilerin ilgisinin yüksek olduğu gözlemlenmiştir. Bu nedenle öğretmen kılavuz kitaplarında derslerin bilgisayar destekli işlenmesine yönelik etkinliğe yer verilmelidir.

Okullarda kullanılan bilgisayarların; öğrencilerin amaçları doğrultusunda eğitim öğretimi destekleyen yazılımlar barındırması gerekmektedir. Aksi durumlarda öğrenciler bilgisayarı kullanırken amaç dışına çıkarak hedeflenen istendik davranışları kazanamayacaklardır.

Yapılan çalışmanın sadece geleneksel öğretim yöntemi ile karşılaştırılması yapılmıştır. Bir sonraki çalışmalarda bilgisayar destekli eğitimin diğer tüm öğretim modelleri ile karşılaştırılması yapılabilir.

Bilgisayar destekli öğrertim yönteminin fen eğitimi dışında diğer tüm derslerde olan etkisi de araştırılabilir. Yine sonraki çalışmalarda kız ve erkek öğrenciler arasında ki tutum ve başarı farkı araştırılabilir.

\section{Teşekkür}

Sayın Volkan Aydın Arııı ve sayın Ali Günay Balım'a çalışmamız içeriğinde kullandığımız başarı testini ve tutum ölçeğini kullanmamıza izin verdikleri için ayrı ayrı teşekkür ederiz.

\section{KAYNAKÇA}

Akçay, S., Aydoğdu, M., Yildirim, H. İ. \& Şensoy, Ö. (2005). Fen eğitiminde ilköğretim 6. sınıflarda çiçekli bitkiler konusunun öğretiminde bilgisayar destekli öğretimin öğrenci başarisina etkisi. Kastamonu Ĕ̈itim Dergisi, 13(1), 103-116.

Altınışık, S., \& Orhan, F. (2002). Sosyal bilgiler dersinde çoklu ortamın öğrencilerin akademik başarıları ve derse karşı tutumları üzerindeki etkisi. Hacettepe Üniversitesi Ĕgitim Fakültesi Dergisi, 23, 41-49.

Arıc1, V. A. (2013). Fen eğitiminde sanal gerçeklik programlari üzerine bir çalişma: güneş sistemi ve ötesi: uzay bilmecesi ünitesi örneği. Yayımlanmamış Yüksek lisans Tezi, Adnan Menderes Üniversitesi Fen Bilimleri Enstitüsü, Aydın.

Ayas, A., et al. (1993). Development of the Turkish secondary science curriculum. Science Education, 77 (4), 440-443. 
Balım, A. G., Sucuoğlu, H. \& Aydın G. (2009). Fen ve teknolojiye yönelik tutum ölçeğinin geliştirilmesi. Pamukkale Üniversitesi, Ĕ̈itim Fakültesi Dergisi, 25, 33-41.

Barker, P. \& Yeates, H., (1985). Introducing Computer Assisted Learning, England: Prentice Hall International.

Başkaya, A. A. (2015). İlköğretimde görev yapan branş öğretmenlerinin bilgisayar destekli ĕgitime ilişkin tutumlarinin incelenmesi. Yayınlanmamış Yüksek Lisans Tezi. Marmara Üniversitesi, Fen Bilimleri Enstitüsü, İstanbul.

Çamlı, H. (2009). Bilgisayar destekli zihin haritalama tekniğinin ilkoğretim 5. sınıf öğrencilerinin akademik basarilarina, fene ve bilgisayara yönelik tutumlarina etkisi. Yayımlanmamış Yüksek Lisans Tezi, Ege Üniversitesi Fenbilimleri Enstitüsü, İzmir.

Çeliker, H. D. (2012). Fen ve teknoloji dersi güneş sistemi ve ötesi: uzay bilmecesi ünitesinde proje tabanli ögrenme uygulamalarinin ögrenci başarilarina, yaratici düşünmelerine, fen ve teknolojiye yönelik tutumlarina etkisi. Yayınlanmamış Doktora Tezi, Dokuz Eylül Üniversitesi, Eğitim Bilimleri Enstitüsü, İzmir.

Çepni, S., (2008). Effects of computer supportes instructional materials (CSIM) in removing misconceptions about concepts: light, light source and seeing, Energy Education Science Technology Part B: Socialand Educational Studies, 1(2), 51- 85.

Güven, G., \& Sülün, Y. (2012). Bilgisayar destekli öğretimin 8. sınıf fen ve teknoloji dersindeki akademik başarıya ve öğrencilerin derse karşı tutumlarına etkisi. Türk Fen Eğitimi Dergisi, 9(1), 68-79.

Hannefin, M. \& Peck, K. L. (1988). The Design, Devolopment, and Evaluation of Instructional Software, New York: Macmillan.

Hassan Zadeh Baranı, G. (2014). Bilgisayar destekli animasyonla öğretim yönteminin fen bilgisi ögretmenliği fizik 4 (modern fizik) dersi ile ortaöğretim 11. sınıf modern fizik dersindeki akademik başariya etkisi. Yayınlanmamış Yüksek Lisans Tezi, Çukurova Üniversitesi Sosyal Bilimler Enstitüsü, Adana.

Milli Eğitim Bakanlığı. Bakanlı̆̆ın vizyon ve misyonu. Web: http://www.meb.gov.tr/vizyon-misyon/duyuru/8851 $(8.12 .2015)$

Kahraman, Ö. (2007). İlköğretim 7. Sınıf fen bilgisi dersi fizik konularının öğretilmesinde bilgisayar destekli öğretimin ögrrenci tutum ve başarısına etkisi. Yayımlanmamış Yüksek Lisans Tezi, Pamukkale Üniversitesi Fenbilimleri Enstitüsü, Denizli.

Karaçöp, A., Doymuş, K., Doğan, A. \& Koç, Y. (2009). Öğrencilerin akademik başarılarına bilgisayar animasyonları ve Jigsaw tekniği etkisi. Gazi Ĕ̆itim Fakültesi Dergisi, 29 (1), 211-235.

Karasar, N. (2005). Bilimsel Araştırma Yöntemi, Ankara: Nobel Yayın Dağıtım.

Köroğlu, H. \& Yeşildere, S. (2004). İlköğretim yedinci sınıf matematik dersi tamsayılar ünitesinde çoklu zeka teorisi tabanlı öğretimin öğrenci başarısına etkisi. Gazi Eğitim Fakültesi Dergisi, 24(2), 25-41.

Öz, Ö. Ö. (2014). İlkögrretim 6. sinıflarda fen bilgisi dersinde uzayi keşfediyoruz ünitesinin öğretiminde bilgisayar destekli ögretimin öğrenci başarisina etkisi. Yayımlanmamış Yüksek Lisans Tezi, Çukurova Üniversitesi Eğitim Bilimleri Enstitüsü, Adana.

Öz, S. (2014). Biyoloji öğretiminde hazırlanan bilgisayar destekli ögretim materyallerinin başarl, kalıcılık ve bilgisayara yönelik tutuma etkisi (dolaşım ve sindirim sistemi örneği). Yayınlanmamış Doktora Tezi, Gazi Üniversitesi Eğitim Bilimleri Enstitüsü, Ankara.

Şahin, T.Y. \& Yıldırım, S. (1999). Öğretim Teknolojileri ve Materyal Geliştirme. Ankara: Anı Yayıncılık.

Sökücü, F. G. (2014). A study on the attitudes of eltteachers toward computer assisted language learning. Unpublished Master's Thesis, Çağ University, Institute of Social Sciences Department of English Language Teaching, İstanbul.

Sönmez, E., Dilber, R., Karaman, I. \& Şimşek, D. (2005). Fizik laboratuarında kullanılan deney malzemeleri üzerine bir çalışma. Kazım Karabekir Ĕ̌itim Fakültesi Dergisi, 11, 591- 604.

Sulak, S. A. (2002). Matematik Dersinde Bilgisayar Destekli Öğretimin Öğrenci Başarı ve Tutumlarına Etkisi. Doktora tezi, Selçuk Üniversitesi Fen Bilimleri Enstitüsü, Konya.

Taş, N. (2014). Bilgisayar Destekli Öğretim Üzerine Sistematik Bir Derleme. Yayınlanmamış Yüksek Lisans Tezi, Atatürk Üniversitesi Eğitim Bilimleri Enstitüsü, Erzurum.

Uşun, S. (2000). Dünyada ve Türkiye’ de Bilgisayar Destekli Öğretim. Ankara: Pagem A Yayıncılık.

Uşun, S. (2004). Bilgisayar Destekli Öğretimin Temelleri. Ankara: Nobel Yayınları.

Yalın, H. (2002). Öğretim Teknolojileri ve Materyal Geliştirme. Ankara: Nobel Yayınları.

Yechshzhanova, Z. (2014). Bilgisayar destekli öğretim ve mobil öğretim için geometri dersinin içeriğinin geliştirilmesi. Yayınlanmamış Yüksek Lisans Tezi, Gazi Üniversitesi Bilişim Enstitüsü, Ankara.

Zonturlu, S. (2014). A study on computer assisted language learning and the development of learner Autonomy.Unpublished Master's Thesis, Çă̆ University Institute of Social Sciences Department of English Language Teaching, İstanbul. 
Ek 1.

Derste Kullanılan Solar System Scope Programından Alınan Ekran Görüntüleri

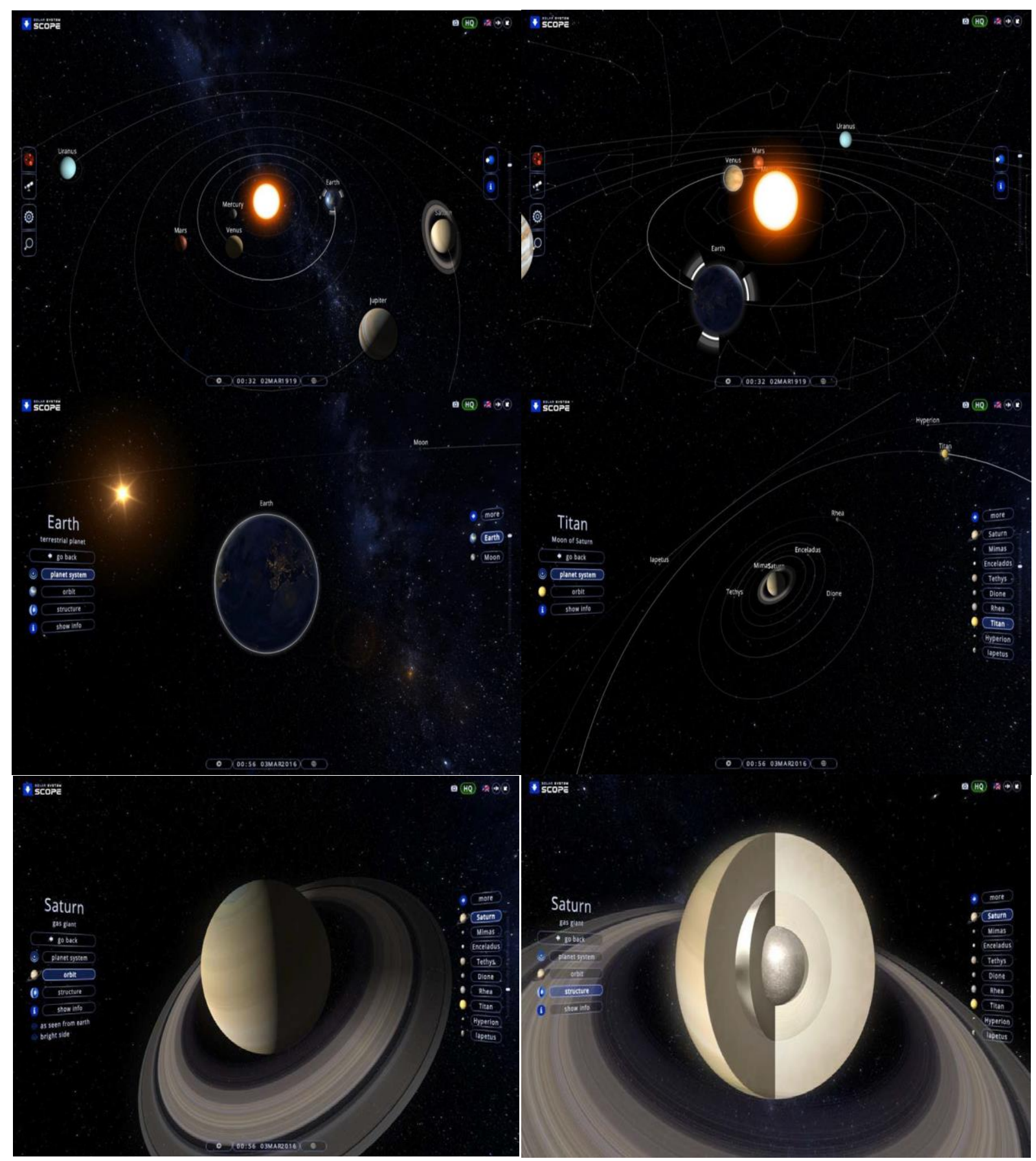




\section{Ek 2 .}

\section{Fen ve Teknoloji Dersi Başarı Testi Soruları}

5. Aşağıdaki şekillerden hangisi bir kuyruklu yıldıza aittir?

A.

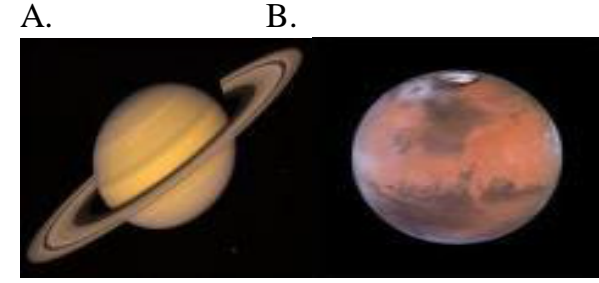

C.

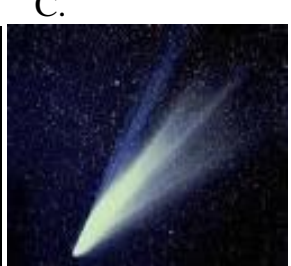

D.

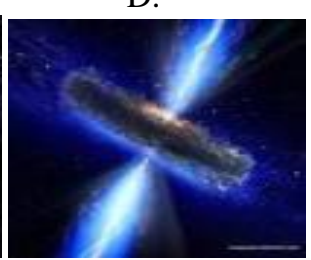

6. Aşağıdakilerden hangisi gezegenler ve yıldızlar arasındaki farklardan birini oluşturmaz?
A. Bize yakınlıkları
B. Parlaklıkları
C. Büyüklükleri
D. Yüzey sıcaklıkları

9. Işık yılı ile ilgili aşağıdaki bilgilerden hangisi doğrudur?
A. Işığın bir yıldaki yayılma hızı
B. Işı̆̆ı̀ bir yılda aldığı yol
C. Işığın Güneş'ten Dünya'ya bir yılda gelmesi
D. Işı̆̆ın 1 milyon kilometre yol alması için gereken zaman

10. Aşağıdaki şekillerden hangisi bir göktaşı örneği olabilir?

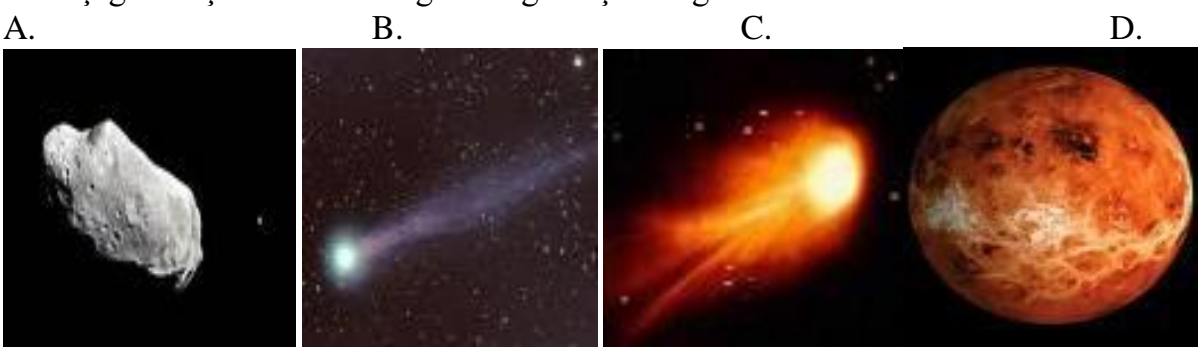

11. Aşağıdaki gezegenlerden hangileri güneşe en yakın ve en uzak gezegenlerdir?
A. Merkür-Jüpiter
B. Merkür- Neptün
C. Neptün-Jüpiter
D. Neptün -Mars

17. Aşağıdaki modellerden hangisi güneş sisteminde Güneş Ay ve Dünya'nın konumunu temsil edebilir? (G: Güneş, D: Dünya, A: Ay )
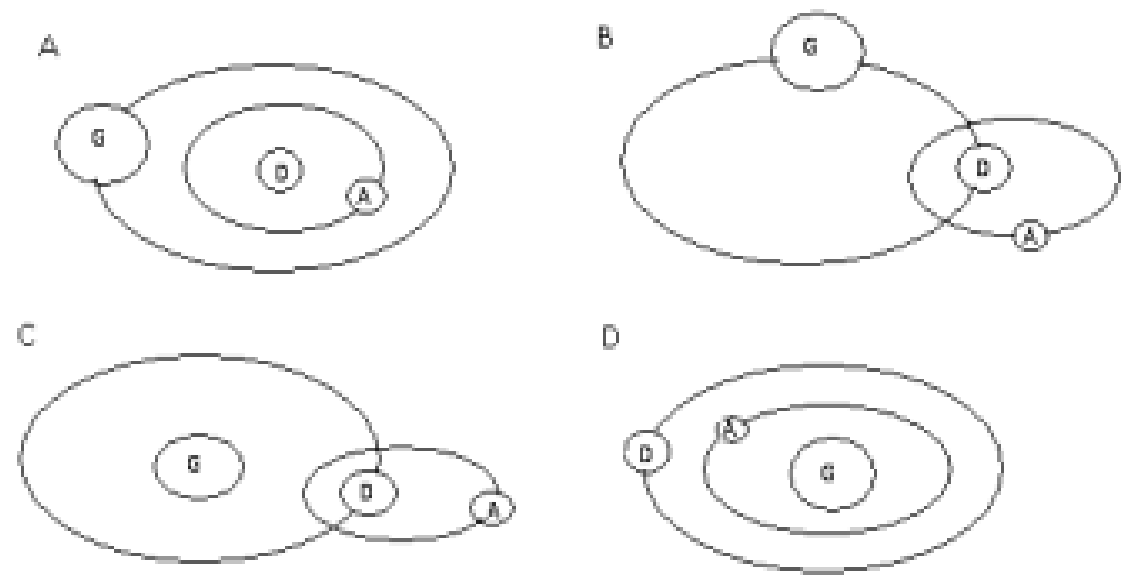

D

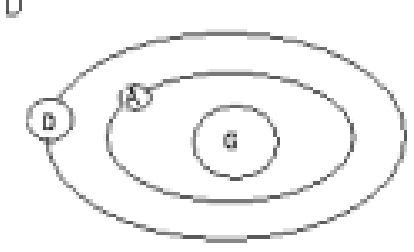


Ek 3.

Fen ve Teknolojiye Yönelik Tutum Ölçeği

1. Fen ve teknoloji dersi zevklidir.

2. Fen ve teknoloji konularıyla ilgili kitaplar okumayı severim.

3. Fen ve teknoloji dersi beni korkutur.

4. Fen ve teknoloji derslerinde zaman çabuk geçer.

5. Fen ve teknoloji dersine çalışırken canım sıkılır.

6. Fen ve teknoloji dersi olmasa öğrencilik zevkli olur.

7. Fen ve teknoloji dersini severim.

8. Fen ve teknoloji dersi eğlenceli bir derstir.

9. Fen ve teknoloji haftalık ders saati azaltılırsa mutlu olurum.

10. Fen ve teknoloji dersini dinlemeyi severim.

11. Fen ve teknoloji dersi sıkıcı bir derstir.

12. Fen ve teknoloji dersine girmek istemiyorum.

13. Doğa olaylarının nasıl gerçekleştiğini merak ederim.

14. Fen ve teknoloji dersinde deney yapmak hoşuma gider

15. Fen ve teknoloji dersinde zaman geçmek bilmiyor.

16. Fen ve teknoloji dersinde konular azaltılırsa mutlu olurum.

17. Fen ve teknoloji alanında yapılan yeni buluşlar dikkatimi çeker

18. Bilim ve teknoloji alanındaki yeni gelișmeleri öğrenmek hoşuma gider.

19. Fen ve teknoloji dersine girerken büyük sıkıntı duyarım.

20. Fen ve teknoloji dersinde deney yapmaktan nefret ederim.

21. Fen ve teknoloji dersinde öğrendiğim konuları günlük hayatımda uygulamak hoşumagider.

22. Ders dışında fen ve teknoloji konularıyla ilgili konuşmaktan hoşlanırım.

23. Fen ve teknoloji dersinden nefret ederim.

24. Fen ve teknoloji dersinde sıkıldığım için ders dişı şeyler düşünürüm.

25. Fen ve teknoloji dersinde deney yapmak derse olan ilgimi artırır.

26. Bilim ve teknolojiyle ilgili kitap ve dergileri okumaktan hoşlanırım.

27. İleride fen ve teknoloji alanında çalışmak isterim.

28. Fen ve teknoloji derslerinde tahtaya kalkmak istemem.

29. Fen ve teknoloji derslerinde dikkatimi toplamakta zorlanırım.

30. Fen ve teknoloji öğretmeni olmak isterim.

31. Fen ve teknoloji benim için ilgi çekicidir.

32. Bana yetki verseler okuldaki bütün fen ve teknoloji derslerini kaldırırım.

33. Fen ve teknoloji ile ilgili her şey dikkatimi çeker.

34. Fen ve teknoloji dersinde zilin çalmasını dört gözle beklerim.

35. Fen ve teknoloji dersinde uykum gelir

36. Fen ve teknoloji ile ilgili bir problemle uğraşmak bana zevk verir.

37. Fen ve teknoloji dersi seçmeli olsaydı, yine fen ve teknoloji dersini seçerdim.

38. Yillarca fen ve teknoloji okusam yine de bikmam.

39. Diğer derslere göre fen ve teknoloji dersine çalışmaktan daha çok hoşlanırım.

40. Fen ve teknoloji dersini sadece sınıf geçmek için çalışırım.

41. Fen ve teknoloji sınavları beni korkutur.

42. Fen ve teknoloji dersinde dikkatim dağılır.

43. Fen ve teknoloji derslerinde kendimi rahat hissederim.

44. Fen ve teknoloji dersinde öğretmenim konuyu anlatırken kendimi huzursuz hissederim. 


\title{
The Impact of Computer Aided Education on the Student Success and the Student Attitude against the Lesson in the "Solar System and Beyond, Space Riddle" Unit
}

\author{
Regaip ŞAHIN \\ Kafkas University, Turkey \\ e-mail: Rsahin66@hotmail.com \\ Uğur AKBABA \\ Kafkas University, Turkey \\ e-mail: ugurakbaba@hotmail.com
}

Citation: Şahin, R. \& Akbaba, U. (2018). The Impact of Computer Aided Education on the Student Success and the Student Attitude against the Lesson in the "Solar System and Beyond, Space Riddle" Unit. E-Kafkas Journal of Educational Research, 5(1), 10-24.

\section{Extended Summary}

Introduction: Computer is seen as an indispensable educational tool today's. The concept of computer-aided teaching method is settled in educational literature. As in all branches, computers are widely used in science education. The impact of computer-aided teaching on student achievement is a very popular research topic nowadays. This study was carried out in order to investigate this effect particularly in science lesson. The study is a semi-experimental study appropriate to the pretest-posttest form with control group. In this study, the effect of "computer-aided teaching" on the level of access to the aims of science and technology course was investigated.

Method: The research was carried out at Şehit Recep Eşiyok Secondary School in Bayburt province center in Turkey. This school has the necessary computer infrastructure. The universe of the work is the students of Şehit Recep Eşiyok Secondary School located in the Bayburt province center. The sampling is the 7th grade students in the school. The research group consists of 40 students. There were 20 students in the experimental group ( 9 female, 11 male) and 20 students in the control group (12 female, 8 male). The research was carried out at the 7th grade level on the "Solar System and Beyond; Space Riddle" unit. One experiment and one control group were established. Computer-aided teaching method for the experimental group and traditional teaching method for the control group were applied. This application lasted for 4 weeks. The sixth grade year-end scores of the students were accepted as pre-tests. At the end of the study, the data were collected using Science and Technology Achievement Test and Attitude Scale against the Lesson. Training and development studies were carried out for the students' basic computer skills in the school where the research was carried out. In addition, it was observed that the computer skills of students were almost the same. Statistical analyzes of the obtained data were made by using SPSS 22.00 package program. Prior to statistical analysis, it was examined whether the data exhibit normal distribution. For this, the normality test was applied in the SPSS 22.00 package program and the data showed normal distribution. For this reason, t-test was used in the research. Some assumptions must be made to use these tests. That's why, the t-test assumptions were examined and the necessary assumptions were found to be satisfied. The following results were obtained after the data evaluation.

Findings: 6th grade science and technology course final exam scores were analyzed. In the performed statistical analyzes, It was observed that there was no significant difference in pre-test results of the students in the groups $[t(38)=0,541 ; p=0,592 ; p>0,05]$. It is seen that there is a statistically significant difference in the t-test results applied for the final test academic achievement scores $(p=0.000 ; p<0.05)$. The final test academic achievement averages of the students in the experimental group were 77.80 and the final test academic achievement averages of the students in the control group were 48.75. There is no statistically significant difference in the t-test results for post-test academic attitude scores $[t(38)=-1,461 ; p=0.152 ; p>0,05]$.

Conclusion and Discussion: (1) It was observed that the experimental group students had higher academic achievement scores than the control group students. (2) There was no significant difference between attitude scores for science and technology lesson in terms of groups.

As a result, the following suggestions can be made; the use of computer aided teaching method in all lessons will be very useful for students and teachers. It has been observed that the activities related to the Solar System Scope program are very interesting for the students. For this reason, these types of activities should be included in the teacher's guidebooks. Computers used in schools must have software that supports education and 
training. Otherwise, students will not be able to gain targeted attitudes. The work done was compared only with the traditional teaching method. In the next studies, computer aided teaching method can be compared with all other teaching methods. The effect of computer assisted teaching method in all other courses besides science education can also be investigated. In subsequent studies, the attitude and achievement gap between male and female students can be investigated. 